DOI 1052646

\title{
HUBUNGAN DUKUNGAN KELUARGA DENGAN STRES PADA IBURUMAH TANGGA (IRT) BERSTATUS HIV-AIDS DI KLINIK ANIMHA RSUD MERAUKE
}

\author{
Maria Evelina Maturbongs ${ }^{1}$, Rifki Sakinah Nompo ${ }^{2}$, Makmun Rosidi ${ }^{3}$ \\ ${ }^{1)}$ Mahasiswa STIKes Jayapura \\ ${ }^{2)}$ Prodi Ners STIKes Jayapura \\ ${ }^{3)}$ SMA Negeri 1 Sentani \\ email: zrevimaturbongs774@gmail.com
}

\begin{abstract}
ABSTRAK
Pendahuluan: Klinik Animha Merupakan salah Satu pusat rujukan pasien HIV-AIDS di papua dan sejak beberapa tahun terakhir dan terus meningkat. Salah satu hal yang perlu diperhatikan adalah cukup tingginya kasus HIV-AIDS ini terjadi pada ibu rumah tangga (IRT) yang memerlukan dukungan keluarga. IRT dengan HIV-AIDS yang kurang mendapatkan dukungan dari keluarga, disebabkan oleh tingginya stigma terkait penyakit HIV-AIDS sehingga anggota keluarga yang menderita penyakit ini sering dianggap telah melanggar normanorma dalam keluarga dan memalukan keluarga. Pada akhirnya mereka sering dikucilkan, ditelantarkan bahkan diisolasi dari lingkungan sehingga membuat IRT berstatus HIV-AIDS menjadi stres. Oleh sebab itu peneliti merasa perlu dilakukan penelitian untuk mengetahui apakah ada hubungan dukungan keluarga dengan penurunan stres pada IRT berstatus HIV-AIDS. Metode: Deskriptif kuantitatif dengan analisa uji spearman rho menggunakan koesioner yang di lakukan pada 30 responden IRT berstatus HIV-AIDS pada klinik Animha. Hasil: Dukungan keluarga kategori tinggi sebanyak 25 orang $(83,3 \%)$, kategori sedang 4 orang $(18,3 \%)$ dan kategori rendah 1 orang $(3,3 \%)$. Tingkatan stres terdapat pada kategori sedang sebanyak 25 orang $(83,3 \%)$ dan kategori rendah sebanyak 5 orang $(16,7 \%)$. Kesimpulan: Terdapat hubungan yang rendah antara hubungan keluarga dengan penurunan stres sangat kuat antara dukungan keluarga dengan penurunan stress $(\mathrm{r}=0,199)$ berpola negatif yang berarti bahwa semakin tinggi rendahnya dukungan keluarga tidak mempengaruhi peningkatan atau penurunan stres IRT HIV-AIDS. Bagi klinik Animha RSUD Merauke untuk tetap mempertahankan bahkan meningkatkan mutu pelayanan dan pengobatan yang sudah berjalan dengan baik. Hal ini sangat berdampak pada kualitas hidup bagi IRT berstatus HIV-AIDS tersebut.
\end{abstract}

Kata Kunci: Dukungan keluarga, IRT, Stres

\section{ABSTRACT}

Introduction: The Animha Clinic is one of the reference centers for HIV-AIDS patients in Papua and since the last few years and had continued to increase. One thing to note is the high number of HIV-AIDS cases that occur in housewife (IRTs) who need family support. Housewife with HIV-AIDS who do not have support from their families are caused by the high stigma associated with HIV-AIDS so family members who suffer from this disease are often seen as violating family norms and humiliating their families. In the end they are often ostracized, ignored and even isolated from the environment so that the housewife with HIVAIDS becomes stressed. Therefore, researchers feel the need to conduct research to find out whether there is a relationship between family support and stress reduction on housewife with HIV-AIDS. Method: Descriptive quantitative with analysis using spearman rho, questionnaires performed on 30 housewife as respondents with HIV-AIDS at Animha clinic. 
Results: Family support in high category has 25 people (83.3\%), medium category has 4 people (18.3\%) and low category has 1 person (3.3\%). Levels of stress are in medium category 25 people (83.3\%) and low categories 5 people (16.7\%). Conclusion: There is a low correlation between family relations and stress reduction which is very strong between family support and decreased stress $(r=0,199)$ with negative pattern which means that the higher the low family support does not affect the increase or decrease in stress of housewife with HIV-AIDS. For the Animha clinic in Merauke Hospital to maintain and even improve the quality of services and treatment that has been going well. This greatly affects the quality of life for the housewife with HIV-AIDS.

Keywords: Family Support, Housewife, Stress

\section{PENDAHULUAN}

Acquired Immuno Deficiency Syndrom (AIDS) merupakan kumpulan gejala penyakit yang disebabkan oleh virus HIV (Human Immunodeficiency Virus) yang dapat menular dan mematikan (Bare \& Smeltzer, 2005). Virus tersebut menyerang sistem kekebalan tubuh manusia. Akibatnya, individu yang terinfeksi akan mengalami penurunan daya tahan tubuh yang ekstrim sehingga mudah terjangkit penyakitpenyakit infeksi dan keganasan yang dapat menyebabkan kematian (Price \& Wilson, 2006). Epidemi HIVAIDS saat ini telah melanda seluruh Negara di dunia. Penyakit ini menyebar dengan cepat tanpa mengenal batas Negara dan pada semua lapisan penduduk.

Secara global WHO mencatat jumlah HIV- AIDS hingga akhir tahun 2015 terdapat 1,1 juta orang meninggal, terinfeksi HIV 2,1 juta orang dan 36,7 juta orang yang hidup dengan HIV (WHO, 2015). Salah satu tujuan pembangunan berkelanjutan atau Sustainable Development Goal (SDG) ialah menghentikan epidemik HIV-AIDS di dunia tahun 2030

(Hastuti dkk, 2015). Di Indonesia menurut laporan Ditjen Pemberantasan Penyakit dan Penyehatan Lingkungan (P2PL) Kemenkes RI menyebutkan jumlah kasus kumulatif HIV-AIDS di Indonesia periode tahun 1987 - 30 Juni 2015 sebanyak 291.465 kasus yang terdiri atas 208.909 kasus HIV, 82.556 kasus AIDS dan angka kematian 14.234 kasus. Sedangkan untuk Papua sendiri menurut data Dinkes Propinsi Papua Tahun 2016 terdapat 25.233 penderita HIV-AIDS, HIV dengan jumlah sebanyak 9.326 kasus, AIDS 15.871 kasus dan kematian 1.836 kasus.

Berdasarkan pengambilan data awal di Dinkes Kabupaten Merauke jumlah kasus HIV- AIDS dari tahun 1992 sampai Oktober 2017 terdapat 2051 kasus terdiri dari laki-laki 941 orang atau 45,9 \%, perempuan 1064 orang atau 51,9\%, IRT 397 orang atau $19,4 \%$ dan Kasus kematian 551 orang (dari tahun 1992 sampai Maret 2017), data ini dikumpulkan dari 25 Puskesmas, 4 Rumah Sakit, 1 Pusat kesehatan reproduksi, dan bidan praktek. Salah satu hal yang perlu diperhatikan pada IRT dengan HIV-AIDS adalah dukungan keluarga. Masih banyak ditemui IRT dengan HIV-AIDS yang kurang mendapatkan dukungan dari keluarga. Hal ini disebabkan oleh karena tingginya stigma yang terkait dengan penyakit HIV-AIDS sehingga anggota keluarga yang menderita penyakit ini sering dianggap telah melanggar normanorma dalam keluarga dan memalukan keluarga. Pada akhirnya mereka sering dikucilkan, ditelantarkan bahkan diisolasi dari lingkungan (Purnama \& Haryani, 2006). Dukungan keluarga dibutuhkan oleh IRT dengan HIV-AIDS sebagai support system atau sistem pendukung utama sehingga IRT dapat mengembangkan respon atau koping yang 
efektif untuk dapat beradaptasi denganbaik dalam menangani stresyang dihadapi terkait penyakitnya baik fisik, psikologi maupun sosial (IYW, 2005; Lasserman \& Perkins, 2001). Mekanisme koping mempengaruhi kualitas hidup secara signifikan, individu yang mampu mengontrol stres dengan pemecahan masalah dengan pendekatan perilaku yang baik akan memiliki kualitas hidup lebih baik daripada yang tidak menggunakan mekanisme koping dalam mengatasi masalahnya (Basavaraj., et al, 2010).

Berdasarkan pengambilan data awal dari Klinik Animha yang merupakan pusat layanan untuk pasien HIV-AIDS dibagian Papua Selatan mendapat pelayanan secara komprehensif dan berkesinambungan. Data dari Klinik Animha pasien yang masuk dalam layanansebanyak 86 kasus baru yaitu dari bulan Januari-Oktober 2017 diketahui laki-laki sebanyak 27 orang dan perempuan sebanyak 59 orang dan data pada tahun 2015 khusunyaIRT sebanyak 59 kasus,sedangkan pada tahun 2016 sebanyak 54 kasus dan data untuk kasus IRT terbaru pada bulan JanuariOktober 2017 sebanyak 37 kasus baru. Dilihat dari data diatas hampir tiap bulan terdapat kasus ibu rumah tangga baru yang masuk dalam layanan Perawatan Dukungan dan Pengobatan (PDP). Dimana rata-rata ibu rumah tangga masuk dalam layanan PDP terlihat stres denganstatus terdiagnosa HIV-AIDS. Mereka belum bisa menerima status sebagai pasien HIV- AIDS sehingga terkadang terjadi denial dan mereka merasa putus asa serta merasa hidupnya tidak berarti lagi apalagi tanpa dukungan keluarga dan orang-orang terdekat.

Berdasarkan uraian di atas maka peneliti tertarik untuk meneliti hubungan antara dukungan keluarga dengan stres pada ibu rumah tangga dengan status HIV-AIDS.

\section{METODE PENELITIAN}

Jenis penelitian ini menggunakan deskriptif kuantitatif. Jumlah total populasi pada bulan Januari-Agustus 2017, sebanyak 37 pasien baru yang berperan sebagai ibu rumah tangga. Teknik pengambilan sampel menggunakan accidental sampling, dimana pengambilan jumlah sampel ini dilakukan dengan cara kebetulan, jika sesuai dengan kriteria peneliti. Peneliti membatasi sampel menggunakan minimal sampel berjumlah 30 responden. Kuesioner yang digunakan terdiri dari kuesioner dukungan keluarga yang terlebih dahulu dilakukan uji validitas dan kuesioner Perceived Stress Scale (PSS) untuk mengetahui tingkat stres.

\section{HASIL PENELITIAN}

\section{Univariat}

Dalam analisis univariat ini peneliti memaparkan mengenai kriteria responden (umur, pendidikan dan pekerjaan), dukungan keluarga dan tingkat stres.

\begin{tabular}{|c|c|c|}
\hline \multicolumn{3}{|l|}{ Responden } \\
\hline Kriteria & Frekuensi & $\%$ \\
\hline \multicolumn{3}{|l|}{ Umur } \\
\hline$\leq 20$ tahun & 2 & 6,7 \\
\hline 21-30 tahun & 9 & 30 \\
\hline $31-40$ tahun & 12 & 40 \\
\hline 41-50 tahun & 5 & 16,7 \\
\hline $51-60$ tahun & 1 & 3,3 \\
\hline$\geq 60$ tahun & 1 & 3,3 \\
\hline Total & $\underline{30}$ & 100 \\
\hline \multicolumn{3}{|l|}{ Pendidik } \\
\hline anSD & 6 & 20 \\
\hline SM & 6 & 20 \\
\hline $\mathbf{P}$ & 9 & 30 \\
\hline SM & 9 & 30 \\
\hline A & 30 & 100 \\
\hline \multicolumn{3}{|l|}{ Perguruan } \\
\hline Tinggi & & \\
\hline Total & & \\
\hline
\end{tabular}

Berdasarkan tabel diatas, menunjukan bahwa pada kriteria responden berdaskan umur yang tertinggi pada kelompok umur 31-40 tahun sebanyak 12 orang $(40 \%)$ dan terendah pada kelompok umur 51-60 tahun dan $\geq$ 60 tahun sebanyak 1 orang $(3,3 \%)$. Kriteria responden berdasarkan pendidikan. Dari 30 responden yang diteliti 9 orang $(30 \%)$ berpendidikan perguruan tinggi, 9orang (30\%) SMA, 6 orang $(20 \%)$ berpendidikan SMP dan 6 orang $(20 \%)$ berpendidikan SD. Kriteria responden berdasarkan Pekerjaan. Dari 30 
responden yang diteliti semua responden bekerja sebagai IRT sebanyak 30 orang $(100 \%)$.

\begin{tabular}{|c|c|c|}
\hline Kriteria & Frekuensi & $\%$ \\
\hline \multicolumn{3}{|l|}{ DukunganKelua } \\
\hline rga & 1 & 3,3 \\
\hline Rendah & 4 & 18,3 \\
\hline Sedang & 25 & 83,3 \\
\hline Tinggi & $\underline{30}$ & 100 \\
\hline
\end{tabular}

keluarga. Dari 30 responden sebagian besar responden yang diteliti memiliki dukungan keluarga yang tinggi sebanyak 25 orang $(83,3 \%), 4$ orang $(18,3 \%)$ yang memiliki dukungan keluarga yang sedang dan 1 orang $(3,3 \%)$ memiliki dukungan keluarga yang rendah.

\begin{tabular}{cccc}
\multicolumn{3}{c}{ Tabel 3 Tingkat Stres } \\
\cline { 1 - 1 } Kriteria & & Frekuensi & \\
\cline { 1 - 1 } Tingkat & & \\
Stres & & & 16,7 \\
Ringan & & 25 & 83,3 \\
Sedang & & $\underline{30}$ &
\end{tabular}

Total

Kriteria responden berdasarkan tingkat stres. Dari 30 responden sebagian besar responden yang diteliti memiliki tingkat stres yang sedang sebanyak 25 orang $(83,3 \%)$ dan 5 orang $(16,7 \%)$ memiliki tingkat stres yang rendah.

\section{Bivariat}

Uji korelasi Spearman di gunakan untuk mengetahui hubungan dukungan keluarga dengan penurunan stres pada ibu rumah tangga berstatus HIV-AIDS di Klinik Animha RSUD Merauke.

Tabel 4 Hubungan Dukungan

Keluarga Dengan Penurunan

Stres Pada Ibu Rumah Tangga berstatus HIV AIDS

\begin{tabular}{|c|c|c|}
\hline Variabel & Sig (2-tailed & $r$ \\
\hline $\begin{array}{l}\text { Dukungan } \\
\text { Keluarga - Stre }\end{array}$ & 0,25 & $-0,19$ \\
\hline
\end{tabular}

Berdasarkan tabel 4 diketahui bahwa nilai Correlation Coefficient sebesar $r=-0,199$ dengan sig. (2-tailed) adalah $0,291 \rho>0.05$. Hal ini berarti Ho gagal terima artinya ada hubungan antara dukungan keluarga dengan tingkat stres pada IRT berstatus HIV-AIDS. Tingkat hubungan antara kedua variabel negatif (-) 0,199 , yang berarti kekuatan hubungan berada pada tingkat hubungan sangat rendah, selain itu hubungan bernilai negatif ini berarti dukungan keluarga tidak saling mempengaruhi peningkatan stres pada IRT berstatus HIV-AIDS.

\section{PEMBAHASAN}

\section{Karakteristik Responden}

Usia berpengaruh pada pola pikir seseorang dan pola pikir berpengaruh terhadap perilaku seseorang. Usia seseorang secara garis besar menjadi indikator dalam setiap mengambil keputusan yang mengacu pada setiap pengalamannya, dengan semakin bertambahnya usia maka dalam menerima sebuah instruksi dan dalam melaksanakan suatu prosedur akan semakin bertanggung jawab dan berpengalaman. Semakin cukup umur seseorang akan semakin matang dalam berpikir dan bertindak (Evin, 2010). Hal ini sejalan dengan hasil penelitian yang didapatkan bahwa kriteria responden berdasarkan umur yang tertinggi pada kelompok umur 31-40 tahun sebanyak 12 orang (40\%).

Dari hasil penelitian diketahui pendidikan responden paling banyak berada pada tingkat pendidikan SMA 9 orang $(30 \%)$ dan Perguruan tinggi sebanyak 9 orang $(30 \%)$. Notoatmodjo (2007) menyatakan bahwa tingkat pendidikan dapat berpengaruh pada IRT yang berstatus HIV-AIDS. Tingkat pendidikan akan menentukan mudah atau tidaknya seseorang dalam menyerap dan memahami pengetahuan yang mereka peroleh, pada umumnya semakin tinggi pendidikan seseorang makin baik pula pengetahuannya. Seseorang dengan pendidikan yang baik, lebih matang terhadap proses perubahan pada dirinya, sehingga lebih mudah menerima pengaruh dari luar yang positif, obyektif dan terbuka terhadap berbagai informasi termasuk informasi kesehatan.

Dari hasil penelitian diketahui bahwa 
mayoritas dukungan keluarga tinggi sebanyak 25 orang $(83,3 \%)$. Keluarga menjadi unsur penting dalam kehidupan seseorang, karena keluarga merupakan sistem yang saling berhubungan dan saling ketergantungan dalam memberikan dukungan dari para anggota- anggota keluarga seperti kasih sayang, rasa aman dan perhatian serta harmonisasi dalam menjalankan perannya masing-masing menurut Friedman (2010).

Dukungan keluarga dibutuhkan oleh IRT dengan HIV-AIDS sebagai support system atau sistem pendukung utama sehingga IRT dapat mengembangkan respon atau koping yang efektif untuk dapat beradaptasi dengan baik dalam menangani stres yang dihadapi terkait penyakitnya baik fisik,psikolgimaupun sosial.

Pada klinik Animha dibentuk support group yang bekerja sama dengan LSM YASANTO untuk mendukung dan saling berbagi informasi tentang penyakit dan pengobatan kepada IRT yang berstatus HIV- AIDS, serta berbagai kegiatan yang melibatkan anggota support group yang terdiri dari IRT berstatus HIV-AIDS. Adapun kegiatan yang dilakukan seperti: penyuluhan HIVAIDS pada sekolah-sekolah maupun di masyarakat. Mereka pun dilatih untuk menjadi konselor sehingga dapat membantu menjaring masyarakat yang beresiko terhadap penyakit HIVAIDS. Ini dilakukan oleh IRT yang berstatus HIVAIDS, yang telah membuka status dirinya. Kegiatan-kegiatan ini membuat IRT berstatus HIV-AIDS lebih percaya diri dalam menjalani kehidupannya tanpa merasa dikucilkan oleh keluarga dan masyakat. Kegiatan- kegiatan ini jugas dapat mengurangi stres pada IRT berstatus HIV-AIDS.

\section{Pengaruh Hipnoterapi Terhadap Penurunan Nyeri Pasien Post Operasi Fraktur}

Dari hasil penelitian diketahui bahwa nilai Correlation Coefficient sebesar $r=-0,199$ dengan sig. (2-tailed) adalah 0,291. Hasil ini sedikit menjauh dari penelitian Kaijage (2010), yang menunjukkan bahwa IRT berstatus HIVAIDS stresnya akan lebih berat dari pada orang lain. Akan tetapi dengan adanya dukungan keluarga yang didapatkannya maka stresnya akan lebih berkurang. Hasil penelitian Kaijage ini mendukung penelitian tersebut. Penelitian ini mendapat hasil bahwa terdapat hubungan yang kuat antara hubungan keluarga dengan hubungan stres $(\mathrm{p}<0,005)$. Hal ini dapat terjadi karena berbagai hal pertama responden penelitian ini merupakan pasien di sebuah klinik yang memberikan dukungan terhadap IRT berstatus HIV-AIDS. Kedua responden rata-rata pada usia dewasa muda. Pada saat dewasa muda, seseorang akan menjalani beberapa perubahan dalam kehidupannya dengan banyaknya tuntutan. Ketiga karena responden penetian ini sudah menyatakan bahwa memiliki dukungan yang tinggi dilihat dari dukungan keluarga, pada uji statistik dukungan keluarga menunjukkan tidak ada hubungan signifikan dengan tingkat stres.

Dari hasil penelitian juga diketahui bahwa tingkat hubungan antara kedua variabel negatif (-) 0,199 yang menunjukkan bahwa tinggi rendahnya dukungan keluarga tidak saling mempengaruhi peningkatan stres. Hal ini mungkin terjadi karena selain dukungan keluarga, Klinik Animha juga memberikan dukungan/ upaya untuk menurunkan stres pada IRT berupa kegiatan-kegiatan bakti sosial, pertemuan KDS untuk berbagi informasi yang melibatkan IRT berstatus HIV-AIDS pada Klinik Animha. Kegiatan ini untuk mendukung para ODHA untuk berbagi informasi serta pengalaman yang telah di lalui oleh ODHA sehingga menjadi pengalaman buat ODHA yang lama maupun ODHA yang baru. Hal ini dikarenakan Klinik ANIMHA menjadi media untuk mendukung para IRT 
berstatus HIV-AIDS dengan memberikan informasi dan supporting group sehingga mempengaruhi cara pandang IRT berstatus HIV-AIDS terhadap penyakit yang dideritanya baik tentang penyakit maupun pengalaman.

Selain itu menurut Yusuf (2004), faktor pemicu stres dapat diklasifikasikan dalam beberapa kelompok sebagai berikut: 1) Stressor fisik biologik, seperti: penyakit yang sulit disembuhkan, cacat fisik atau kurang berfungsinya salah satu anggota tubuh, wajah yang tidak cantik atau ganteng dan postur tubuh yang dipersepsi tidak ideal (seperti: terlalu kecil, kurus, pendek, atau gemuk), 2) Stressor psikologik, seperti: negative thingking atau berburuk sangka, frustasi (kekecewaan karena gagal memperoleh sesuatu yang diinginkan),hasud (iri hati atau dendam), sikap permusuhan, perasaan cemburu, konflik pribadi dan keinginan yang diluar kemampuan, dan 3) Stressor sosial, seperti iklim kehidupan keluarga. Hubungan antara anggota keluarga yang tidak harmonis (broken home), perceraian, suami atau istri selingkuh, suami atau istri meninggal, anak yang nakal (suka melawan kepada orang tua, sering membolos dari sekolah, mengkonsumsi minuman keras dan menyalahgunakan obat-obatan terlarang) sikap dan perlauanorang tua yang keras.

\section{KESIMPULAN}

1. Dukungan keluarga di Klinik Animha RSUD Merauke dengan kategori tinggi sebanyak 25 orang $(83,3 \%)$, sedang 4 orang $(18,3 \%)$ sedangkan rendah 1 orang $(3,3 \%)$.

2. Tingkatan stres pada penderita HIVAIDS di Klinik RSUD Merauke, dalam kategori sedang sebanyak 25 orang $(83,3 \%)$, dan tingkat rendah sebanyak 5 orang $(16,7 \%)$.

3. Terdapat hubungan yang rendah antara hubungan keluarga dengan penurunan stres sangat kuat antara dukungan keluarga dengan penurunan stres $(r=0,199)$ berpola negatif yang berarti bahwa semakin tinggi rendahnya dukungan keluarga tidak mempengaruhi peningkatan atau penurunan stres IRT HIV-AIDS.

\section{DAFTAR PUSTAKA}

Basavaraj, et. Al. (2010). Quality of Life In HIV-AIDS. JOURNAL Departement of Demaartology, venereology and leprosy, JSS Medical College. JJS University, Mysore, Karnataka, India..

Friedman, M. (2010). Buku Ajar Keperawatan Keluarga: Riset, Teori dan Praktek, Edisi Ke-5. Jakarta: EGC.

IYW. (2005). Pengaruh Dukungan Keluarga Terhadap Perubahan Respon Sosial Emosional Pasien $H I V$-AIDS. Diakses pada tanggal 8 Desember2017darihttp://ners.unair.a c.id.

Kaijage (2010). The Imfluence Of Stres An Social Support On Adherence To Health Promotion Strategies By People Living With HIH-AIDS In Dar Es Salam.

Lasserman, J \& Perkins O, O. (2001). Coping With The threat of AIDS: The Role of Soscial Support. Journal Departemen of Phsyciatry. Universitas of Nourth Carolina School of Medicine. Diakses pada tanggal 8 Desember 2017 dari http://ajp.pshyciatryonline.org.

Notoadmodjo, S. (2010). Metodelogi Penelitian Kesehatan. Jakarta: Rineke Cipta.

Price, S.A \& Wilson, L.M.(2006). Patpfisiologi:Konsep Klinis Proses Penyakit, Edisi 6, Volume 1. Jakarta: EGC.

Purnama, A \& Haryanti, E. (2006). Stigma dan Diskriminasi terhadap ODHA. Jakarta:Sagung Seto.

Yusuf, Syamsu. (2004). Psikologi Perkembangan Anak dan Remaja. Bandung: PT. Remaja Rosdakarya. 